it is, very desirable that women should acquire such medical knowledyeas would fit them to make improved nurses, and even to practise in the zenanas of the East, but that was not the preposition we had to discuss. The proposal was to place women on a perfect equality with men as medical practitioners. The evils of this proposal have often been ably pointed out by members of the profession; but, speaking as an outsider, I venture to trouble you with the reasons which weigh with me. The evil effects of the change will not be witnessed in the present generation, but I fear the next will bave occasion to rue the innovation which we are now inaugurating. I fear the idea will grow up among ladies, particularly among young ladies, that there is something indelicate in their consulting a gentleman; and should such an idea arise, it will be full of misery to the comfort of families. It will be a most serious evil if, when a young lady is asked by her parents and friends to crnsult some eminent pbysician, she takes it into her head that some lady doctor will do equally well. I know the trial of having relatives who have preferred to consult bormonpathists and bydropathists, and whom I have lost, with the feeling that they had not received proper treatment. I fear these " medical women" will entail a similar trial on many in the next generation.

Apologising for troubling you, I am, Sir, yours obedient]

Carlton Club, Jane 25th, 1877. R. N. Fowler.

\section{THE COUNCIL ELECTION, COLLEGE OF SURGEONS.}

To the Editor of THE LANCET.

Sir,-The approaching election of members of Council is exciting unwonted interest. Considerations of custom and precedent are cast to the winds, and a keen contest is waged with all the arts and energy of a struggle between rival candidates d la mode. How are bewildered fellows to escape the toils of wit, wine, and womanly graces? Dinners, balls, routs, and the captivating eloquence of ladies surprisingly well informed on matters of Cullege interests and policy, are novel argnments withil too potent to be effectually resisted. For myself, Mr. Editor, I have thrown over the idea of be. stowiug my vote, $n$ the brst men; a sober selection is impracticable I have been canvassed personally and by letter, button-boled and curtain-lectured, dined and dazed in the giddy dance, uatil not the least notion remains to me as to the functions of Councillors, or whether the work they are supposed to have in band is pure self-glorification, or something for the public good. Excuse my too apparent ob. fuscation; an election of the class now in progress has been too much for $m p$. I tried to steady myself by reading the President's report. It took me fully three minutes, but despite the singular conciseness with which questions of grave professional interest are discussed in that interesting and important brochure, I am no better able to form a reasonable judgment. Hitherto I have supposed that the Council of the College represented the Fellows and busied itself with their interests, with now and again a thought for the Members, that the grave concerns of surgical science were included in the area of consideration, and that even professional topics of public moment formed suljects of deliberation. I have awakened from that prosaic dream, and my eyes are nearly opened to the discovery that the Council is a sort of Valbulla, to which gentlemen of a certain age and dignity may aspire, and where, in elegant ease, they pass the bappy hours away, innocuous and inert. Verily the method of the contest befirs the future of the successful. I shall vote for the most agreeable and friendly of the rompetitors.-Your obedient servant, June $27 \mathrm{ih}, 1877$.

\section{A Feliow.}

\section{PRESCRIBING AND DISPENSING.}

\section{To the Editor of Tre LaNCET.}

SrR,- The respective merits of prescribing and dispensing, considered in your leading article on the 16 th inst., have often been forced upon me. I formerly dispers.d, and notwithstanding the disadvantages of doing so, I could at least have the satisfaction of knowing that drugs came from a first rate manufacturer. Since I discontinued dispensing I am again and again an noyed by the complaints and doubts of patients in regard to the drugs supplied to them. Making a fair deduction for grumblers, there is sufficient evidence that prescriptions are not always accurately dispensed.

Surely some control over this state of things can be instituted. The purchasers of such commoditirs as fond have themselves a fair experience, in accordance with which they can check the vendor, besides the eafeguards afforded by law. Happily many druggists are conscientious and wellintentioned; where it is otherwise, there must of ten arise powerful temptations to unfaithful dispensing, against the effects of which patients and practitioners are sadly un. protected. Cannot a commission be instituted for privately analysing drugs supplied, and publishing the results? For my own part, I would gladly suhscribe to the expense.

$$
\text { Yours obediently, }
$$

June, 1877. W. WILBERForCE SMITH,

P.S. -The possible variations in the qualities of drugs are well indicated by the "market reports," which show the immense differences in the wholesale prices of the same drug.

\section{THE ACTION AGAINST MR. BATTESON.}

\section{To the Editor of THE LANCET.}

SIR, - My attention has been directed to a letter in your issue of the 23rd inst., written by Dr. Braxton Hicks, under the above heading.

I was present in court when Dr. Braxton Hicks gave his evidence in favour of the defendant in the above cause, and therefore $I$ am in a position to assert, in reference to the last paragraph of his letter, that what he stated was that in the vast majority of face presentations there was no need to interfere, if my ears as well as the ears of the learned coun. sel for the plaintiff did not deceive us. I do not say that Dr. Hicks may not have intended to state that in face presentations there was need to in terf $\mathrm{re}$, but he is mistaken in stating that he made use of that expression at the court. The importance of his answer to the issue which was raised is apparent, and Dr. Braxton Hicks's evidence on this and other points in the case, and his demeanour while under cross-examination by the plaintuff's couveel, bave been a source of some bewilderment to such of his professional brethren as heard him, ever since.

It is impossible for Dr. Hicks to state on any sort of authority that the objection to the employment of unqualified assistants was at the bottom of the trial, and I must take exception to his assuming something wilhont any evidence in support of his bypotbesis for the purpo-e of raising a discussion in your journal on the conduct of the East London Medical Defence Association.

The action raised the simple issue of negligence or no negligence on the part of the $d_{1} f_{e}$ dant Battesun.

As Dr. Hicks has thought it necessary to allude to a matter without his province in referring to the circumstances under which the action was hrought, I may state that I was retained by the husband of the deceased woman, and attended the inquest on his behalf. The inquest did not end in an acquittal, as Dr. Hicks states, but one of the assistants (Smytb), who admitted that he had reseived no medical education properly so termed - the man who had chief charge of the case-was censured by the cor $n+r$ 's jury; and it further transpired in the course of the inquest that he bad been previously censured by a coroner's jury while in the defendant's employment.

I should have thought it wonld have been more becoming on the part of Dr. Braxton Hicks to bave refrained from discussing the merits of a case in your columns in which he was concerned as a witness for the deferdant, and a barrister of the same name (bis son I believe) prof-ssionally concerned as junior connsel on behalf of the defendant at the bearing before the learned judye of the Whitechapel County Court.

I am, Sir, your faithful servant,

Clement J C. Pridham, Solicitor or 1 he Paaintuff in the action.

John-street, Bedford-row, W.C., June 266h, 1877. 